Neth. J. Pl. Path. 90 (1984) 181-197

\title{
Effects of the saprophytic leaf mycoflora on growth and pro- ductivity of winter wheat
}

\author{
R. RABBINGE ${ }^{1}$, A. BROUWER ${ }^{2}$, N.J. FOKKEMA ${ }^{2}$, J. SINKE ${ }^{3}$ and T.J. STOMPH ${ }^{1}$ \\ 1 Department of Theoretical Production Ecology, Agricultural University, Bornsesteeg 65, \\ 6708 PD Wageningen, the Netherlands \\ 2 Willie Commelin Scholten Phytopathological Laboratory, Javalaan 20, 3742 CP Baarn, the \\ Netherlands \\ ${ }^{3}$ Centre for Agrobiological Research, Bornsesteeg 65, 6708 PD Wageningen, the Netherlands
}

Accepted 16 May 1984.

\begin{abstract}
The effects of the saprophytic mycoflora and its interference with cereal aphids on growth and yield of winter and spring wheat was studied in field experiments in 1980, 1981 and 1982.

Yields varied between 5000 and $8000 \mathrm{~kg}$ dry matter of kernels per ha. The effect of the saprophytic mycoflora on yield was determined in different treatments: A) no control measures against cereal aphids and saprophytic and necrotrophic fungi, B) no control of cereal aphids, control of saprophytic and necrotrophic fungi, C) control of cereal aphids and control of saprophytic and necrotrophic fungi, D) control of cereal aphids and stimulation of saprophytic mycoflora and E) control of cereal aphids, no control of saprophytic and necrotrophic fungi nor stimulation of saprophytic mycoflora.

Considerable differences in top densities of saprophytic mycoflora (10 times as large in A and $\mathrm{D}$ as in $\mathrm{B}$ and $\mathrm{C}$ ) were determined. The consequences of these differences for the growth and productivity of wheat were minor. A negative effect of saprophytic mycoflora on the yield could not be detected in 1981 and 1982, whereas a small positive significant effect was found in 1980 . This stimulation may have been due to competition between necrotrophic fungal pathogens and saprophytic mycoflora. As a result of favourable weather conditions necrotrophic fungal pathogens were very numerous in 1980 and could form an important yield reducing factor. Yield levels may effect the importance of the necrotrophic and saprophytic mycoflora as yield reducing factors. Additionally, in the presence of aphid honeydew captafol was found to be relatively ineffective against saprophytic fungi.
\end{abstract}

Additional keywords: Sporobolomyces, Cryptococcus, Aureobasidium, Cladosporium, yield, captafol.

\section{Introduction}

The saprophytic mycoflora on cereal leaves in temperate climates consists mainly of Sporobolomyces spp. (pink yeasts), Cryptococcus spp. (white yeasts), Aureobasidium pullulans and Cladosporium spp. The yeasts are predominant, and densities of $10^{5}$ yeast cells $\mathrm{cm}^{-2}$ are common on green wheat flag leaves. Newly unfolded leaves are almost sterile and the initial colonization can be considerably stimulated by extraneous nutrient sources such as pollen grains and aphid honeydew (Fokkema, 1971; Fokkema et al., 1979, 1983). 
Aphid honeydew is one of the major causes of yield reduction due to aphids (Rabbinge et al., 1981; R. Rabbinge, G. Coster and G.W. Ankersmit, unpublished results). Leaf coverage by honeydew impedes $\mathrm{CO}_{2}$ assimilation, promotes leaf senescence and stimulates necrotrophic and saprophytic fungi. Detailed analyses of yield reduction due to cereal aphids have demonstrated, both experimentally and theoretically, that the indirect effects of yield reduction (hampering $\mathrm{CO}_{2}$-assimilation, promoting senescence) become relatively and absolutely more important with increasing yield levels (Rabbinge et al., 1983; R. Rabbinge, G. Coster and G.W. Ankersmit, unpublished results). With respect to the effect of honeydew on fungi, it has been demonstrated that the saprophytic phyllosphere mycoflora is able to antagonize infection by necrotrophic pathogens such as Septoria nodorum and Cochliobolus sativus and that this may neutralize negative effects of necrotrophic pathogens on yield (Fokkema et al., 1983). On the other hand, direct detrimental effects of saprophytes on cereal yield are occasionally suggested in attempts to explain unexpected yield increases in fungicide trials with low levels of naturally occurring pathogens (Dickingson and Walpole, 1975; Cook, 1981; Mappes and Hampel, 1977; Priestly and Bayles, 1982). To investigate the potentials of the saprophytes to suppress or reduce necrotrophic fungi through competition, more knowledge is urgently needed about the direct effects of saprophytes on necrotrophic fungi and on crop production in the field (Fokkema, 1981). During 1980, 1981, and 1982, therefore the effects of saprophytic mycoflora on yield were investigated in field experiments: by varying the population density of the saprophytes in different treatments, and by an analysis of their effects on yield. The experiments were planned in such a way that damage effects of both cereal aphids and saprophytic fungi could be determined. The damage effects of cereal aphids are discussed elsewhere (Rabbinge et al., 1981).

\section{Material and methods}

Wheat cultivation. The experiments were performed at the experimental farm De Bouwing near Wageningen. The soil is a deep but somewhat irregular river deposit clay soil (lutum fraction 36-60\%). Winter wheat, Triticum aestivum L. cv. Arminda, was sown with a row width of $25 \mathrm{~cm}$ using $135 \mathrm{~kg}$ of seeds per ha (1000 kernel weight 45 g) on 22 October in 1979 and on 17 October in 1980. In 1982 spring wheat cv. Sicco was sown on 19 February. Detailed crop agronomical measures are given in Table 1. The weather conditions differed considerably in the different seasons. Flowering in 1980, 1981 and 1982 starts on 10, 4 and 9 June, respectively. The weather during kernel filling $\left(\mathrm{DC}^{1}=60\right.$ until $\mathrm{DC}=80$, doughy ripe) was cool and wet in 1980 in comparison with the same periods in 1981 and 1982. In 1982 a warm period with extremely high temperatures shortened the kernel filling period. The average temperatures during kernel filling were $14.3,15.2$ and $16.3^{\circ} \mathrm{C}$ in 1980,1981 and 1982 , respectively. Kernel filling periods lasted 34, 42 and 37 days in 1980, 1981 and 1982.

The experiments were executed in a randomized block scheme with six replicates. The individual fields measured $60 \mathrm{~m}^{2}$ in 1980 and 1981, and $45 \mathrm{~m}^{2}$ in 1982, and were separated from each other by buffer fields of the same size. The central parts of the fields (ca. 50\%) were harvested with an 'experimental plot combine'.

${ }^{1}$ DC $=$ Decimal Code, crop development scale described by Zadoks (1981). 


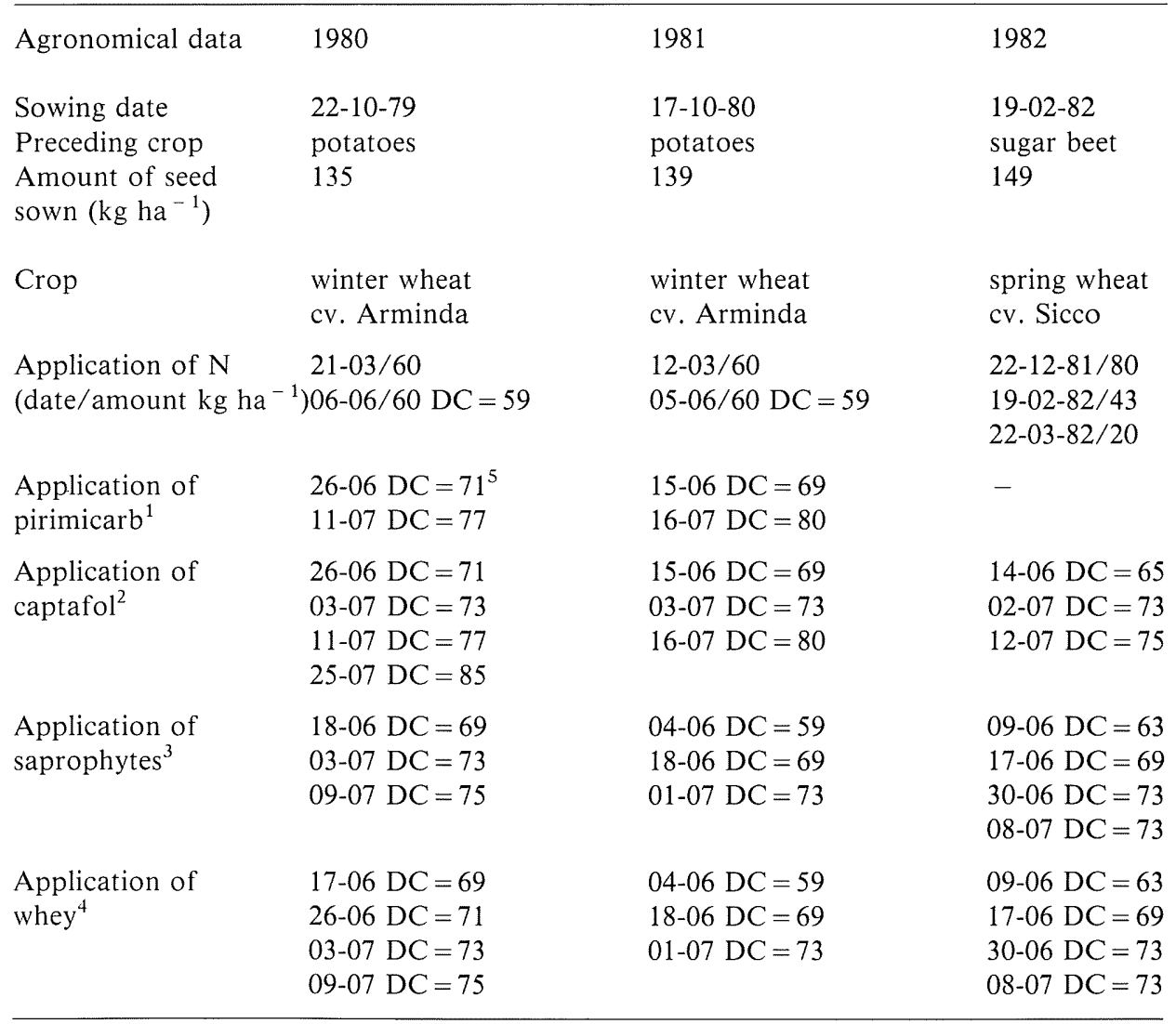

1 Pirimor $\left(0.5 \mathrm{~kg} \mathrm{ha}^{-1}\right)$.

2 Ortho-Difolatan $4 \mathrm{~F}\left(0.751 \mathrm{ha}^{-1}\right.$ in 1980 and 1981) or Ortho-Difolatan-80 (2 kg ha ${ }^{-1}$ in 1982).

3 A combination of Sporobolomyces sp., Cryptococcus sp. and Cladosporium spp.

4 Whey in $2.5 \%$ D.M. with $0.05 \%$ Tween 80 .

${ }^{5}$ DC $=$ Decimal Code, crop development scale described by Zadoks (1981).

Treatments. Different densities of the saprophytic mycoflora were obtained by spraying, fungicides and saprophytes as follows:

A. No control measures against cereal aphids or saprophytic fungi.

B. No control of aphids; control of saprophytic and necrotrophic fungi by captafol (Ortho-Difolatan 4 F, $0.75 \mathrm{I} \mathrm{ha}^{-1}$ in 1980, 1981; Ortho-Difolatan-80, $2 \mathrm{~kg} \mathrm{ha}^{-1}$ in 1982).

C. Control of aphids by pirimicarb (Pirimor, $0.5 \mathrm{~kg} \mathrm{ha}^{-1}$ ); control of fungi as in treatment B.

D. Control of aphids by pirimicarb; stimulation of the saprophytic mycoflora by spraying an aqueous suspension $(0.05 \%$ Tween 80$)$ containing yeast cells of Sporobolomyces roseus $\left(1-4 \times 10^{7} \mathrm{~cm}^{-3}\right)$ and Cryptococcus laurentii var. flavescens $\left(1-4 \times 10^{7} \mathrm{~cm}^{-3}\right)$, and conidia of Cladosporium herbarum $\left(4-11 \times 10^{5} \mathrm{~cm}^{-3}\right)$ 

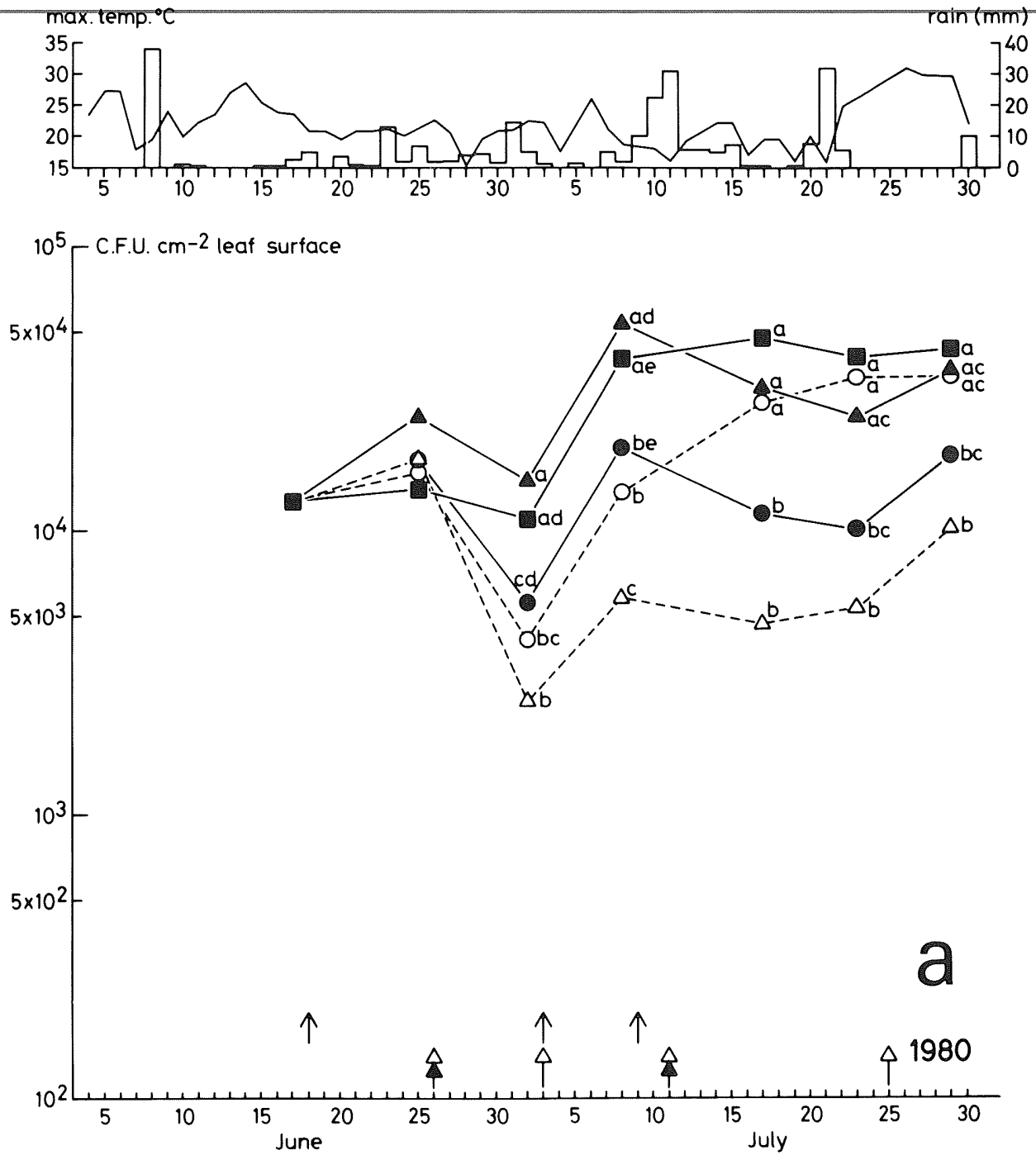

Fig. 1. Effect of different treatments on the seasonal development of pink and white yeasts on wheat flag leaves in 1980 (Fig. 1a), in 1981 (Fig. 1b) and in 1982 (Fig. 1c), and the daily maximum air temperature and rainfall. The treatments consisted of A: Untreated (10), B: captafol $(\bigcirc, \hat{\uparrow}), \mathrm{C}$ : captafol and pirimicarb $(\Delta, \hat{4})$, D: application of yeasts and Cladosporium, except in 1982, at $(\Delta, \uparrow)$, E: pirimicarb at $(, \uparrow)$. The dates of application are indicated by arrows. Sample values of the same sampling date not followed by the same letter are significantly different at $\mathrm{P} \leq 0.05$. 

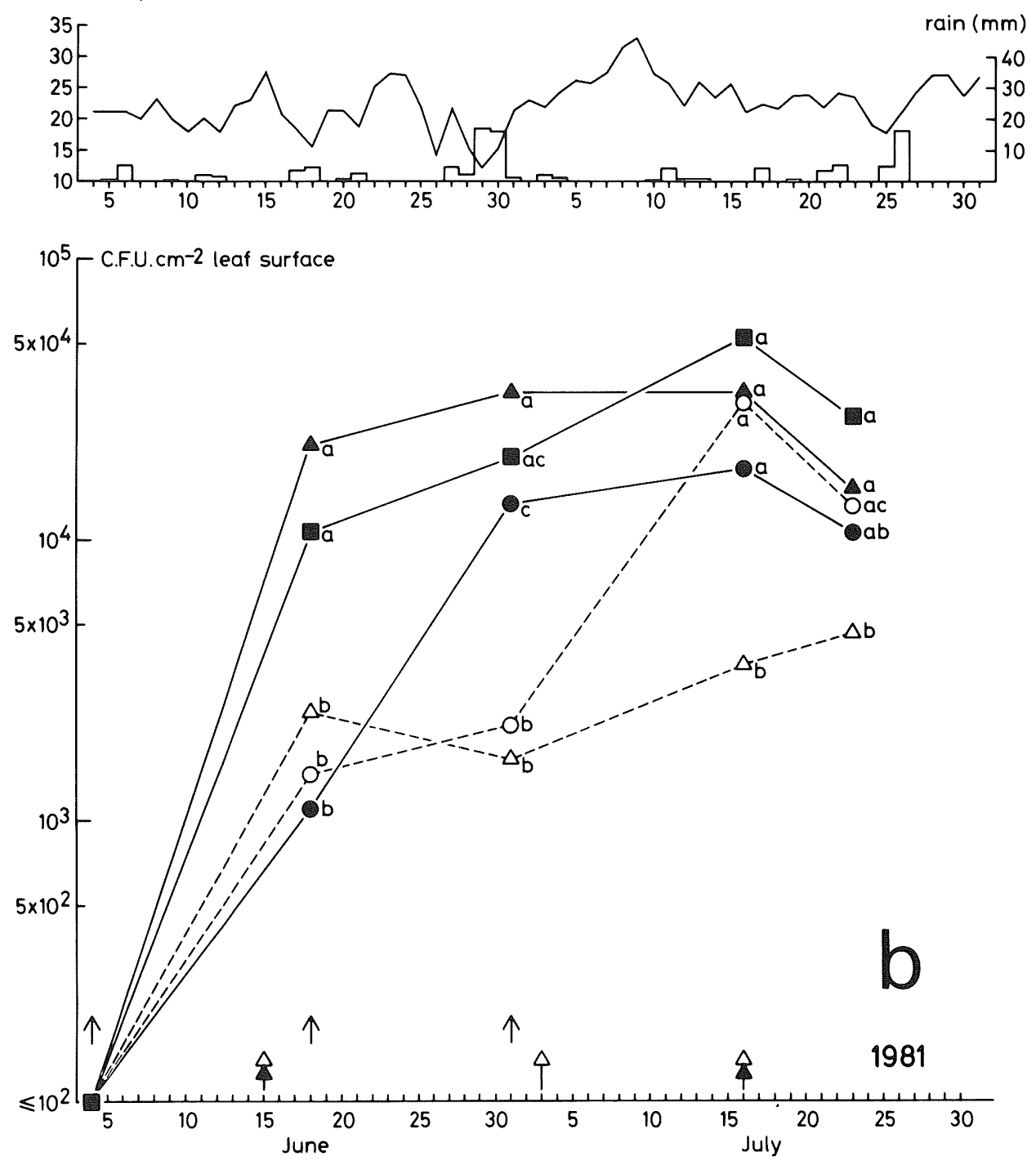

Fig. 1b.

and Cladosporium cladosporioides $\left(8-12 \times 10^{5} \mathrm{~cm}^{-3}\right)$. In 1982 only yeast cells were sprayed since the application of Cladosporium spp. was not very successful in 1980 and 1981 . Wheypowder ( $2 \%$ in 1980,$1981 ; 1 \%$ in 1982) was added to the suspension as a nutrient source. The average analysis of the wheypowder was $4 \%$ water, $1 \%$ fat, $13 \%$ proteins, $73 \%$ lactose and 9\% minerals (Frico, Leeuwarden, personal communication).

E. Control of aphids by pirimicarb; no control of saprophytic and necrophytic fungi. Neth. J. Pl. Path. 90 (1984) 

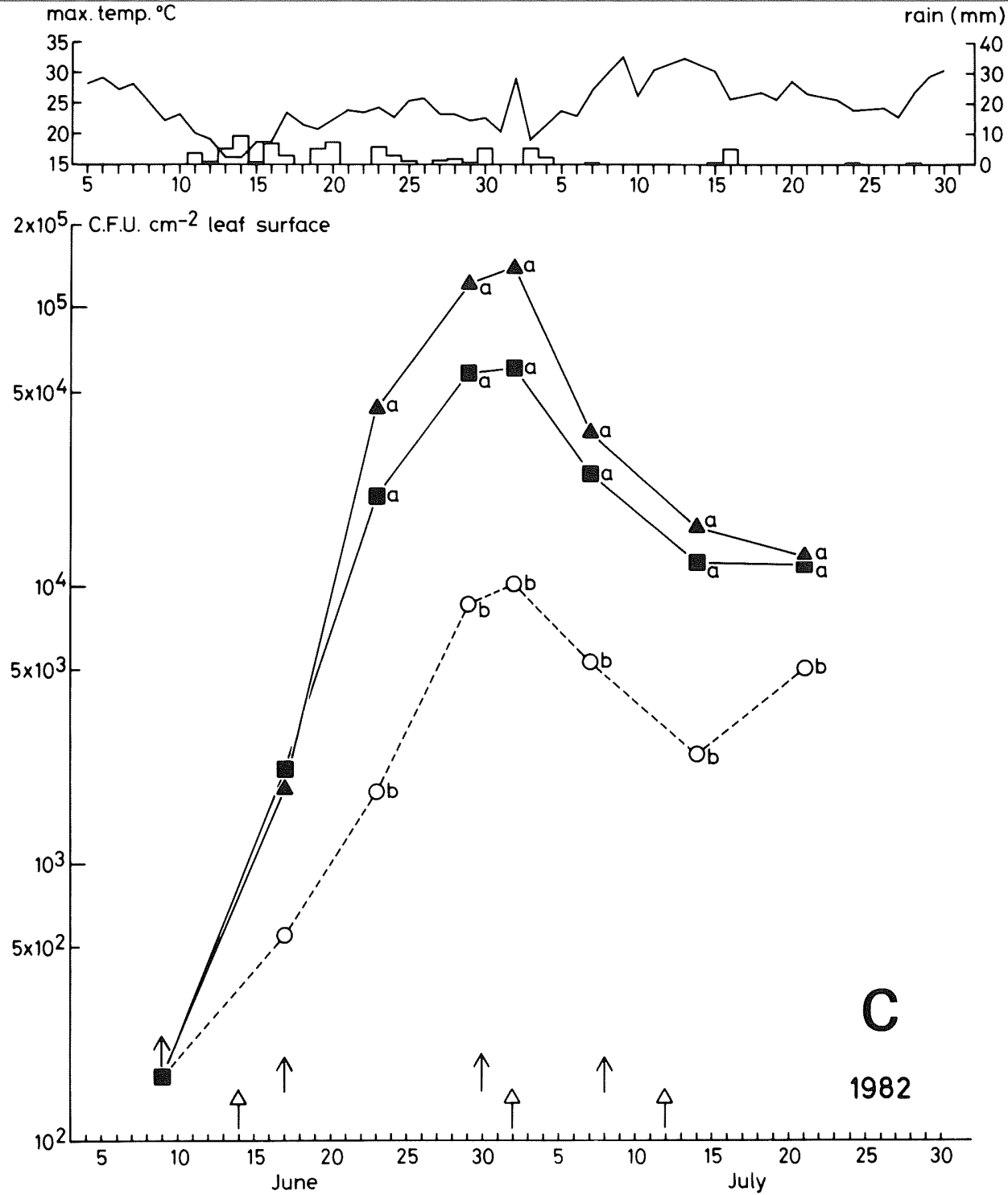

Fig. 1c.

All treatments were applied repeatedly, starting just before flowering (Table 1). During the kernel filling period the crop growth was analyzed regularly by periodic harvesting (the maximum interval was two weeks). The population densities of the saprophytic fungi were determined weekly. To aid the interpretation of the effect of the treatments, daily rainfall and maximum temperature were recorded (Fig. 1).

Inoculum production and analysis of the phyllosphere mycoflora. The yeasts were grown in shake culture at $18{ }^{\circ} \mathrm{C}$ in $1000 \mathrm{~cm}^{3}$ Erlenmeyer flasks with $300 \mathrm{~cm}^{3}$ nutrient 186

Neth. J. Pl. Path. 90 (1984) 
solution containing $0.1 \%$ yeast extract, $1 \%$ bactopeptone and $2 \%$ glucose, under the conditions described by Fokkema et al. (1979). The Cladosporium spp. were grown on PDA-plates $\left(14 \mathrm{~cm}\right.$ diameter) at $23{ }^{\circ} \mathrm{C}$. After 10-14 days of incubation, the conidia were collected by gently scraping the surface of the colony and suspended in $0.05 \%$ Tween 80. Large fragments of mycelium were removed by filtration through nylon gauze. The saprophyte-nutrient mixture was sprayed with a propane operated field plot sprayer (AZO, Ede, the Netherlands) with a spray boom carrying six nozzles, spaced at $25 \mathrm{~cm}$ intervals. Approximately 81 of fluid was sprayed per $100 \mathrm{~m}^{2}$.

The saprophytic colonization of flag leaves from each individual field was assessed by culturing yeast cells, conidia and hyphal fragments, washed from pieces of six leaves (ten in 1982), on agar plates (Fokkema et al., 1979). Necrotic leaf tips were discarded to avoid overestimation of the Cladosporium population. Cladosporium spp. flourish on necrotic leaf area and these leaf tips should therefore be neglected in the countings. The colonization was expressed as the number of colony forming units (C.F.U.) per $\mathrm{cm}^{2}$ leaf surface. When sampling dates coincided with spraying dates, sampling was done first.

Statistical analysis. Differences in saprophytic colonization were tested with a single classification ANOVA followed by the T - or $\mathrm{T}^{\prime}-$ method (Skal and Rohlf, 1981). Homogeneity of variances was tested by Bartlett's test, and if necessary the data were transformed. Differences in yield were analyzed with the Student Newman Keuls multiple range test.

\section{Results}

The saprophytic mycoflora. The colonization patterns of the saprophytes in the three seasons are analyzed with respect to the different treatments, the weather conditions and the occurrence of cereal aphids.

In all years, maximum aphid density was reached at $\mathrm{DC}=77$; there were 18 aphids of all stages per tiller and 173 aphid days (aphid days express the aphid number integrated over time) in 1980, 1.5 aphids per tiller and 36 aphid days in 1981 and 1.8 aphids per tiller and 40 aphid days in 1982.

In 1980 (Fig.la) the sampling and the application of the treatments started relatively late, with the consequence that the yeast population had already reached a level of $10^{4}$ cells $\mathrm{cm}^{-2}$ on the first sampling date. Treatment D (pirimicarb, saprophytes) had no significant effect on the yeast population; initially the population was slightly higher than in the untreated fields (A). The effect of aphids and consequently aphid honeydew on the yeast population is clearly demonstrated by the difference in population densities in treatment $\mathrm{A}$ and treatment $\mathrm{E}$ (pirimicarb). Control of cereal aphids together with captafol sprayings $(\mathrm{C})$ reduced the yeast population about tenfold compared to the untreated plots (A). It is interesting to see that in the absence of the aphicide (B), the fungicidal effect of captafol decreased when aphids became abundant. Similar trends were observed for the blackening fungi Cladosporium spp. and Aureobasidium pullulans (Fig. 2a). Spraying with Cladosporium conidia (D) did not have any effect, and again captafol became less effective at the end of the season if there was no aphid control. Table 2 shows the relative occurrence of the different groups of phyllosphere fungi on one sampling date per year, which represents the general trend. The blackening fungi, among which Cladosporium spp. always 


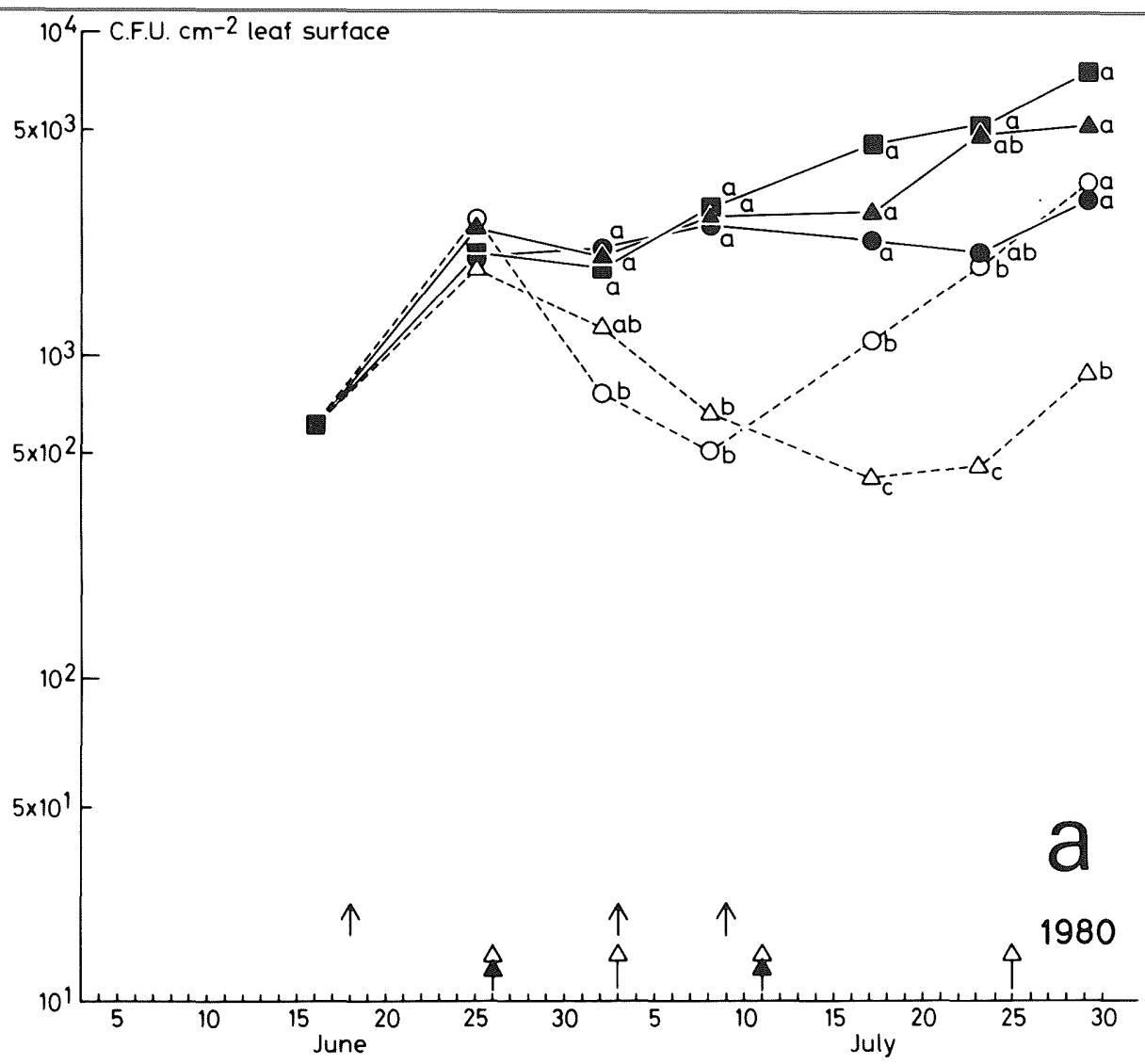

Fig. 2. Effect of the treatments A, B, C, D, and E (see legends Fig. 1) on the seasonal development of the blackening fungi $A$. pullulans and Cladosporium spp. on wheat flag leaves in 1980 (Fig. 2a), in 1981 (Fig. 2b) and in 1982 (Fig. 2c). Sample values of the same sampling date not followed by the same letter are significantly different at $\mathrm{P} \leq 0.05$.

dominated, seldom comprised more than $10 \%$ of the total mycoflora. In 1980 the white yeasts outnumbered the pink yeasts, particularly when captafol had been applied.

In 1981, sampling and treatments started earlier, and a rapid colonization of the newly unfolded flag leaves was noticed in all treatments (Fig. 1b). Spraying with saprophytes (D) slightly increased the yeast population on 18 June and 1 July compared to the untreated leaves (A). Colonization on leaves treated with pirimicarb (E) was low on 18 June. Later in the season captafol was not effective unless pirimicarb had been added. No such interaction could be observed for the blackening fungi (Fig. 2b). Again the spraying with Cladosporium conidia (D) did not result in an increase of the Cladosporium population. When analyzing the composition of the mycoflora, it is obvious that in this season (1981) the pink yeasts were dominant (A, D, E), unless captafol had been sprayed (B, C) (Table 2). 


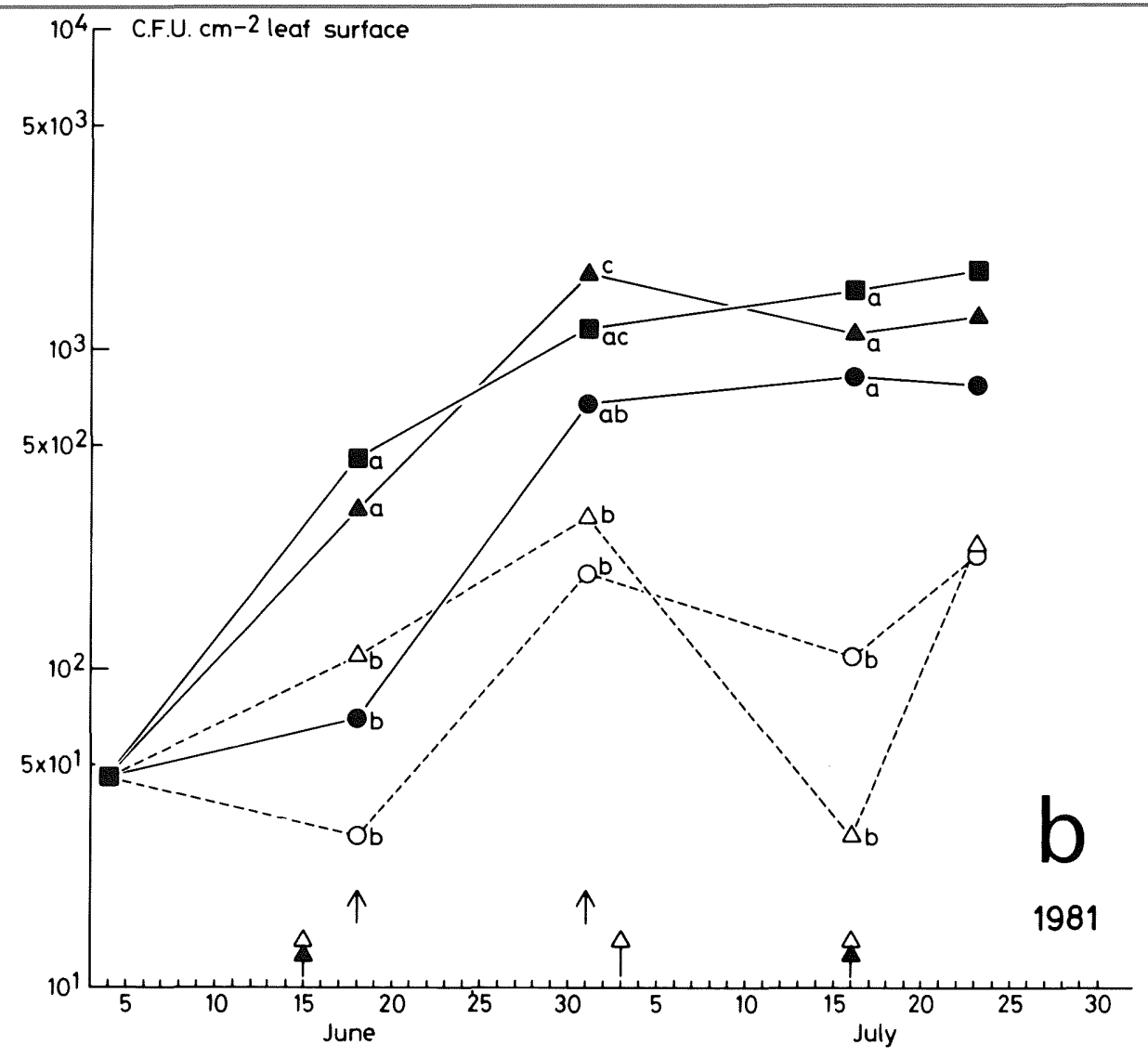

Fig. 2b.

In 1982, pirimicarb was not applied because the aphid population remained extremely low. Therefore, the treatments $\mathrm{E}$ and $\mathrm{C}$ became similar to $\mathrm{A}$ and $\mathrm{B}$, respectively, and the data obtained were considered together as data from A and B. This year the yeast population (Fig. 1c) reached the highest densities, with a slight stimulation due to the saprophyte sprayings (D). Captafol (B) kept the yeast population at a much lower level. A similar trend was observed for the blackening fungi (Fig. 2c). After having reached maximum values at the end of June, the yeast population declined substantially in July, a feature not observed in the other seasons. In this season the white yeasts were in the majority in the yeast population (Table 2) as in 1980.

Crop production. Table 3 shows the yield in kg kernels ha ${ }^{-1}$ ( $16 \%$ moisture). The yield levels were much below the potential in all three years, the potential yield in these three years being estimated by crop growth simulation (Rabbinge, R., G. Coster and G.W. Ankersmit, unpublished results). This is partly due to shortage of nitrogen and bad growing conditions during the start of the growing season. Nitroge content in the kernels (Table 4) was $2.15 \%$ in 1980, $2.25 \%$ in 1981 and $1.93 \%$ in 1982 . The kernel fill- 


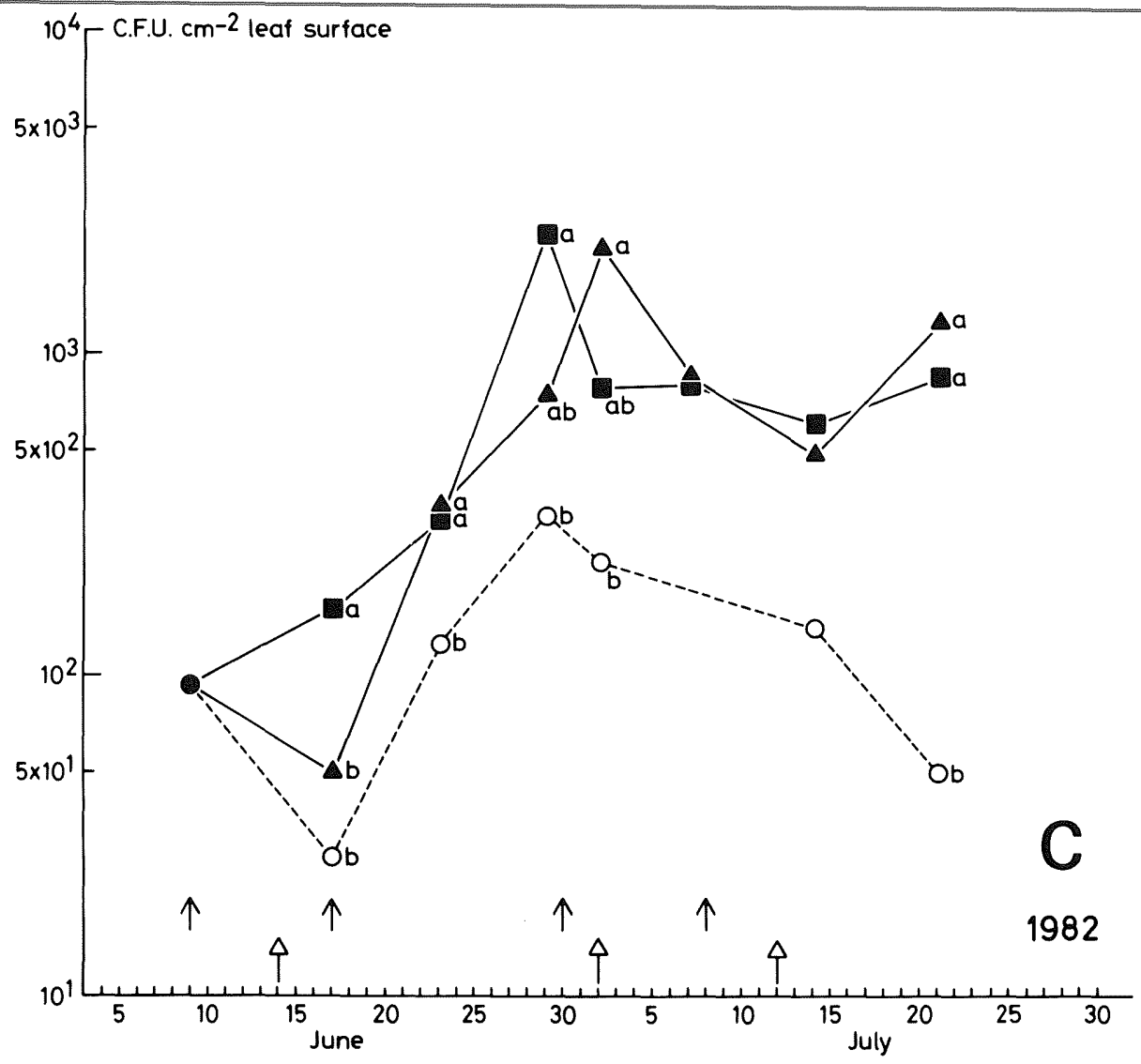

Fig. 2c.

ing periods $(\mathrm{DC}=60-80)$ extended from 34 days in 1980 to 37 days in 1982. On the untreated fields (A) Green Area Duration (GAD), the green area integrated over time, reached values of 70, 90 and 83 days in 1980, 1981 and 1982, respectively. The low value of 1980 may be due to a combined effect of necrotrophic pathogens and unfavourable weather conditions. As well as being cool, 1980 was a relatively wet growing season (Fig. 1a), especially during the flowering and watery ripe stage $(\mathrm{DC}=60-70)$. During this wet period considerable infection by Septoria nodorum and tritici developed. These necrotrophic pathogens were important only in 1980; in 1981 and 1982 these fungi were virtually absent.

Yield differences between years were larger than within years (Table 5). In 1980, the highest yield obtained from treatment D (stimulation of saprophytic mycoflora, control of cereal aphids) differed significantly from yields of the A, B, C and E treatments. In 1981, the highest yield was obtained from treatment $C$ and this was, on a $10 \%$ level, significantly different from the yields of the A, B and D treatments, which had reached about equal values. The 1982 data refer to spring wheat and yields are consequently less then in the previous seasons. The different treatments did not result in significant yield differences. 


\begin{tabular}{|c|c|c|c|c|c|c|c|}
\hline Date & Treatment $^{1}$ & $\begin{array}{l}\text { Total mycoflora } \\
\text { (C.F.U. } \times 10^{-2} \mathrm{~cm}^{-2} \text { ) }\end{array}$ & $\begin{array}{l}\text { White } \\
\text { yeasts }(\%)\end{array}$ & $\begin{array}{l}\text { Pink } \\
\text { yeasts }(\%)\end{array}$ & $\begin{array}{l}\text { A. pullulans } \\
(\%)\end{array}$ & $\begin{array}{l}\text { Cladosporium } \\
(\%)\end{array}$ & $\begin{array}{l}\text { Rest group } \\
(\%)\end{array}$ \\
\hline \multirow[t]{5}{*}{8 July 1980} & A & 439 & 57 & 35 & 1 & 6 & 1 \\
\hline & B & 144 & 84 & 11 & 0.5 & 3 & 1.5 \\
\hline & $\mathrm{C}$ & 68 & 72 & 13 & 1 & 9 & 5 \\
\hline & $\mathrm{D}$ & 572 & 65 & 29 & 0.5 & 5 & 0.5 \\
\hline & $\mathrm{E}$ & 225 & 50 & 36 & 1 & 11 & 2 \\
\hline \multirow[t]{5}{*}{1 Juli 1981} & A & 211 & 20 & 74 & 0.5 & 5 & 0.5 \\
\hline & B & 24 & 70 & 20 & 1 & 8 & 1 \\
\hline & C & 20 & 49 & 33 & 3 & 12 & 3 \\
\hline & $\mathrm{D}$ & 355 & 44 & 51 & 0 & 4.5 & 0.5 \\
\hline & $\mathrm{E}$ & 143 & 22 & 72 & 1 & 4 & 1 \\
\hline \multirow[t]{3}{*}{7 July 1982} & A & 268 & 71 & 25 & 1 & 2 & 1 \\
\hline & $\mathrm{B}$ & 54 & 92 & 8 & 0 & 0 & 0 \\
\hline & $\mathrm{D}$ & 374 & 72 & 25 & 1 & 2 & 0 \\
\hline
\end{tabular}

1 A. No control of cereal aphids or saprophytic and necrotrophic fungi.
B. No control of cereal aphids, control of saprophytic and necrotrophic fungi.
C. Control of cereal aphids, control of saprophytic and necrotrophic fungi.
D. Control of cereal aphids, stimulation of saprophytic mycoflora.
E. Control of cereal aphids, no control of saprophytic and necrotrophic fungi. 
Table 3. Yield (in $\mathrm{kg} \mathrm{ha}^{-1}$ ) of winter wheat in 1980 and 1981 and spring wheat in 1982.

\begin{tabular}{|c|c|c|c|c|c|}
\hline \multirow[t]{2}{*}{ Year } & \multicolumn{5}{|c|}{ Treatment $^{1}$} \\
\hline & A & B & $\mathrm{C}$ & $\mathrm{D}$ & $\mathrm{E}$ \\
\hline 1980 & 6806 & 6775 & 6983 & 7432 & 6786 \\
\hline 1981 & 7762 & 7770 & 8132 & 7782 & 7836 \\
\hline 1982 & 5783 & 5958 & 5898 & 5842 & 5889 \\
\hline
\end{tabular}

${ }^{1}$ For explanations of treatment symbols, see Table 2.

In 1980 , the wheat was seriously infected by $S$. nodorum and tritici, which was apparently only poorly controlled by the captafol sprayings. Treatment D, however, resulted in the highest yield. This may be due to antagonistic activities of the saprophytes Septoria, and not to aphid control which had been applied also in treatment $\mathrm{C}$ and $\mathrm{E}$. The number of kernels per $\mathrm{m}^{2}$ in treatment $\mathrm{D}$ was higher than in treatments A, B, C and E, whereas the 1000 kernel weights did not differ (Table 4).

Apparently the necrotrophic pathogens reduced the number of harvestable kernels. In 1981, the highest yield from treatment $C$ was the result of both an increase of the 1000 kernel weight and of the number of kernels $\mathrm{m}^{-2}$ (Table 4). In 1982, yields from the differently treated fields were about equal; although treatment $\mathrm{C}$ resulted in a relatively high 1000 kernel weight, this had no effect on yields because the other treatments resulted in higher numbers of kernels $\mathrm{m}^{-2}$.

\section{Discussion}

The aim of the experiments was to evaluate the role of the saprophytes as a component of aphid damage in wheat: it being already demonstrated under controlled conditions that honeydew can considerably stimulate both phyllosphere yeasts and blackening fungi (Fokkema et al., 1983). Under field conditions, the phyllosphere mycoflora was manipulated in such a way that the effect of saprophytes stimulated by aphids (A) on yield could be compared with the effect of saprophytes stimulated artificially in the absence of aphids (D). The treatments B, C and E served as controls to distinguish between aphid and fungal damage. Our experiments repeated an experiment performed in 1979 (Rabbinge et al., 1981) in which similar treatments A, B, C and D had been applied. The fungicide used in 1979, however, contained sulphur, which probably controlled mildew, which was present in low infestation levels but made proper interpretation of the effects on yield difficult.

Possible detrimental effects of saprophytes are usually attributed to the group of blackening fungi (Dickinson, 1981), but in our experiments honeydew did not stimulate their occurrence (Fig. 2a, treatment A versus E). Further artificial inoculation with Cladosporium spp. had no effect (Fig. 2a, b; treatment D versus A) and the population of blackening fungi seldom exceeded $10 \%$ of the total mycoflora. Cladosporium spp. prefer dead leaf tissue, which was discarded in our experiments. This implies that an effect of blackening fungi on the physiology of the healthy leaf is unlikely. 
Table 4. Nitrogen content of kernels, 1000 kernel weight and number of kernels $\mathrm{m}^{-2}$ in field experiments with winter wheat in 1980 and 1981 and spring wheat in 1982 .

Year Treatment ${ }^{1}$

\begin{tabular}{|c|c|c|c|c|c|c|c|c|c|c|c|c|c|c|}
\hline \multicolumn{3}{|l|}{ A } & \multicolumn{3}{|l|}{ B } & \multicolumn{3}{|l|}{ C } & \multicolumn{3}{|l|}{$\mathrm{D}$} & \multicolumn{3}{|l|}{ E } \\
\hline$\% \mathrm{~N}$ & $\begin{array}{l}1000 \\
\text { kernel } \\
\text { weight }\end{array}$ & $\begin{array}{l}\text { number } \\
\text { of kern- } \\
\text { nels } \mathrm{m}^{-2}\end{array}$ & $\% \mathrm{~N}$ & $\begin{array}{l}1000 \\
\text { kernel } \\
\text { weight }\end{array}$ & $\begin{array}{l}\text { number } \\
\text { of ker- } \\
\text { nels } \mathrm{m}^{-2}\end{array}$ & $\% \mathrm{~N}$ & $\begin{array}{l}1000 \\
\text { kernel } \\
\text { weight }\end{array}$ & $\begin{array}{l}\text { number } \\
\text { of ker- } \\
\text { nels } \mathrm{m}^{-2}\end{array}$ & $\% \mathrm{~N}$ & $\begin{array}{l}1000 \\
\text { kernel } \\
\text { weight }\end{array}$ & $\begin{array}{l}\text { number } \\
\text { of ker- } \\
\text { nels } \mathrm{m}^{-2}\end{array}$ & $\% \mathrm{~N}$ & $\begin{array}{l}1000 \\
\text { kernel } \\
\text { weight }\end{array}$ & $\begin{array}{l}\text { number } \\
\text { of ker- } \\
\text { nels } \mathrm{m}^{-2}\end{array}$ \\
\hline 2.15 & 46.9 & 14535 & 2.15 & 46.7 & 14507 & 2.08 & 48.6 & 14386 & 2.14 & 47.6 & 15629 & 2.14 & 47.2 & 14377 \\
\hline 2.22 & 43.8 & 17701 & 2.23 & 43.7 & 17780 & 2.25 & 45.0 & 18051 & 2.23 & 44.2 & 17602 & 2.22 & 44.0 & 17809 \\
\hline 1.93 & 37.1 & 15575 & 1.93 & 37.0 & 16103 & 1.95 & 38.6 & 15287 & 1.93 & 36.9 & 15836 & 1.94 & 37.2 & 15830 \\
\hline
\end{tabular}

${ }^{1}$ For explanation of treatment symbols, see Table 2.

Table 5. Results of Student Newman Keuls multiple range test of differences of yield ratios between treatments A, B, C, D and E based on results presented in Table 3 pair by pair.

\begin{tabular}{|c|c|c|c|c|c|c|c|c|c|c|c|c|c|c|c|}
\hline \multirow[t]{2}{*}{ Treatment $^{1}$} & \multicolumn{5}{|c|}{1980} & \multicolumn{5}{|c|}{1981} & \multicolumn{5}{|c|}{1982} \\
\hline & A & B & $\mathrm{C}$ & $\mathrm{D}$ & $\mathrm{E}$ & A & B & $\mathrm{C}$ & $\mathrm{D}$ & $\mathrm{E}$ & A & B & $\mathrm{C}$ & $\mathrm{D}$ & $\mathrm{E}$ \\
\hline A & $x^{2}$ & - & - & 0.01 & - & $x$ & - & 0.01 & - & - & $\times$ & - & - & - & -1 \\
\hline B & $\times$ & $\times$ & - & 0.01 & - & $x$ & $\times$ & 0.01 & - & - & $x$ & $\times$ & - & - & - \\
\hline C & $x$ & $\times$ & $\times$ & 0.01 & - & $\times$ & $\times$ & $\times$ & 0.01 & - & $x$ & $\times$ & $\times$ & - & - \\
\hline $\mathrm{D}$ & $x$ & $x$ & $x$ & $\times$ & 0.01 & $x$ & $x$ & $x$ & $x$ & 0.01 & $x$ & $\times$ & $\times$ & $x$ & - \\
\hline E & $\times$ & $x$ & $x$ & $\times$ & $\times$ & $\times$ & $\times$ & $\times$ & $\times$ & $\times$ & $\times$ & $\times$ & $\times$ & $x$ & $x$ \\
\hline
\end{tabular}

${ }^{1}$ For explanation of treatment symbols, see Table 2.

$\quad 2$ The confidence level is given; no significant difference at the $10 \%$ level;
$\quad \times$ not relevant. 
The yeast sprayings (D) seem ineffective contrary to earlier observations (Fokkema et al., 1979). However, it has been observed before that if the natural population reaches levels of about $10^{4}$ cells $\mathrm{cm}^{-2}$, it cannot be increased artificially (Fokkema et al., 1979). In 1980, leaves in treatment $D$ had saprophyte levels equal to those of the untreated leaves (A) with a substantial aphid population, and much higher than the saprophyte levels on leaves without honeydew (E). In general the treatments resulted in great differences of saprophyte densities with at least a tenfold difference between treatment $\mathrm{A}$ and $\mathrm{D}$ on one hand and treatment $\mathrm{C}$ on the other hand. The crucial question is whether there is any consistent relationship between saprophyte levels and yield.

In 1980, the highest yield was obtained from fields with high densities of saprophytes (D), while fields with good saprophyte control (C) gave some of the lowest yields. In 1980, the treatment with saprophytes may have led to competition with naturally occurring Septoria infections, which have been determined qualitatively and quantitatively by Forrer p.c. in another part of the experimental field. The same phenomenon was seen before under experimental conditions (Fokkema and Van der Meulen, 1976; Fokkema et al., 1979). However, the yeast densities on untreated leaves (A) were only slightly lower than those from treatment D and the low yield resulting from treatment A suggests poor control of Septoria. The discrepancy in the effects on yield may be explained by the possibility that, although the densities were similar, the saprophytes on the treated leaves (D) were more uniformly distributed over the leaf surface than the saprophytes on treatment $\mathrm{A}$. This could be a result of the spraying. The saprophytes (A) colonize aphid honeydew which is as a result of the patchy distributed aphids, deposited in a rather heterogeneous way. Further fresh honeydew deposits may also have stimulated Septoria (Fokkema et al., 1983) in situations with low saprophyte densities. Due to the Septoria infestation in 1980, it is impossible to evaluate the possible negative effects of the saprophytes; their beneficial role, however, did become apparent.

In 1981, yield from treatment C, with the lowest level of saprophytes, was $350 \mathrm{~kg}$ greater than the yield from treatment $\mathrm{D}$, which had the highest saprophyte density. This difference was significant only at the $10 \%$ level. The treatment with captafol only (B) resulted in saprophyte densities equal to those of treatment $\mathrm{C}$ till at least the beginning of July and much lower than those of treatment D (Fig. 1b), but the corresponding yield from treatment B was similar to that of D. Saprophytes seem, therefore, to have no consistent effect on yield. In 1982, aphicide was not applied and consequently the treatments $\mathrm{E}$ and $\mathrm{C}$ were similar to the treatments $\mathrm{A}$ and $\mathrm{B}$, respectively. There was a great difference in saprophytic colonization between the leaves sprayed with fungicides $(C, B)$ and the leaves from the remaining treatments, but still all yields were about equal.

Other experiments (Rabbinge et al., 1983) have shown the importance of yield levels on the nature and size of yield reduction due to cereal aphids. In our experiments such effects could not be demonstrated, as yield levels were below potential and cereal aphids were not numerous. Detailed analyses, simulation studies and field experiments have demonstrated that very high yield levels, $10000-12000 \mathrm{~kg} \mathrm{ha}^{-1}$ (Spiertz, 1982; De Vos, 1977), are only reached when GAD (Green Area Duration) is high. In our experiments at lower yield levels (1980) a positive effect of the saprophytes could be demonstrated. Therefore damage thresholds and control measures should be tailored to the specific circumstances and potentials of a growing crop. 
A direct effect of saprophytic yeasts and filamentous saprophytes on GAD is difficult to demonstrate, since in the field large differences in saprophyte densities can only be achieved by fungicide sprayings which also control necrotrophic pathogens and which may have direct beneficial effects on the plant metabolism (Fokkema, 1981). This problem could have been overcome when our treatment D had consisted of fungicide-resistant saprophytes allowing an overall fungicide treatment following an approach outlined by Fokkema (1983). In our experiments, however, we had to deal with convential agrochemicals and sprayings with saprophytes and nutrients for the creation of different saprophyte levels. Irrespective of the possible side effects of the treatments we may conclude that in 1980 saprophyte sprayings may have increased yield and that in 1981 and 1982 saprophyte sprayings had no effect on yield.

During the experiments a very interesting effect of aphid honeydew on the action of the fungicide captafol became apparent. In 1980 and 1981, the saprophytes were insufficiently controlled by captafol alone (B) when cereal aphids and consequently aphid honeydew occurred. Together with aphid control (C), captafol regained its normal mode of action. A similar trend had been observed in 1979 (Rabbinge et al., 1981). It is unlikely that pirimicarb had such a fungicidal effect, because the pirimicarb addition in treatment $C$ had no additional fungicidal effect in June 1980 when the aphids were still absent and also the saprophytic population of leaves receiving the $\mathrm{D}$ treatment, which includes pirimicarb, did not seem to suffer from this chemical. Besides, experiments under controlled conditions did not reveal a fungicidal side effect of pirimicarb on yeast (unpublished). The meaning of this observation may be important because there is no reason to assume that the activity of captafol would be differently affected when pathogens are involved. It has been demonstrated before that carbohydrates may reduce the effect of fungicides on pathogens (Dunn et al., 1971; Kataria and Grover, 1978) but it is striking to see this happen under field conditions. Aphicides may control honeydew deposition, but also the natural saprophytic mycoflora is capable of removing carbohydrates from the phyllosphere (Fokkema et al., 1983). Therefore, selection of fungicides not affecting the saprophytic yeasts will probably avoid this reduction of fungicidal action and, in addition, conserve the possible ability of these organisms to compete with necrotrophic fungi.

\section{Acknowledgements}

Many students contributed to this study. The assistance of Walter Rossing, Jan Rauwerdink, Wim Mantel and Jan Smelt in the field experiments is kindly mentioned. Thanks are due to Florentine Tebra for the statistical analysis of the colonization data, to Bert van Amersfoort for typing the manuscript, to Dennis Dutscher for making the drawings and to Seamus Ward and Gonnie van Laar for critically reading the manuscript.

\section{Samenvatting}

Het effect van saprofytische bladschimmels en gisten op de groei en produktiviteit van wintertarwe

De effecten van saprofytische schimmels en gisten op de groei en opbrengst van winter-

Neth. J. Pl. Path. 90 (1984) 
deze schimmeldflora met graanluizen is in deze proeven nagegaan.

De produktieniveaus varieerden tussen 5000 en $8000 \mathrm{~kg}$ droge massa aan korrels per ha. Het effect van de saprofytische schimmelflora werd vastgesteld d.m.v. verschillende behandelingen: A: geen bestrijding van graanluizen en geen bestrijding van de saprofyten; B: geen bestrijding van graanluizen, wel bestrijding van de saprofytische schimmelflora; $\mathrm{C}$ : bestrijding van graanluizen en bestrijding van saprofyten; D: bestrijding van graanluizen en stimulering van saprofyten door bespuiting van een wei-oplossing met gisten en zwartschimmels; E: bestrijding van graanluizen en geen bestrijding noch stimulering van gisten en zwartschimmels. Aanzienlijke verschillen in de maximale dichtheden van saprofyten werden vastgesteld (10 $\times$ zo groot bij A en D als bij B en C). De gevolgen van deze verschillen voor de groei en productiviteit van tarwe waren verwaarloosbaar. In 1981 en 1982 kon geen negatief effect van de saprofyten worden vastgesteld, terwijl in 1980 een klein positief significant verschil kon worden aangetoond. Dit laatste is waarschijnlijk veroorzaakt door de concurrentie tussen necrotrofe en saprofytische schimmels en gisten in 1980 .

Tengevolge van zeer gunstige weersomstandigheden waren de necrotrofe schimmels zeer talrijk in 1980 en vormden daarmee een belangrijke opbrengst reducerende factor, die onder deze bijzondere omstandigheden enigszins werd teniet gedaan door de concurrerende saprofyten.

Deze resultaten werden gevonden bij een onder de huidige omstandigheden gemiddeld opbrengstniveau, zodat de aanwezigheid van dit positieve effect bij hogere opbrengstniveaus niet kon worden aangetoond. Tevens werd waargenomen dat captafol in aanwezigheid van honingdauw weinig effect had op de saprofytische schimmels.

\section{References}

Cook, R.J., 1981. Unexpected effect of fungicides on cereal yields. EPPO Bull. 11: 277-285.

Dickinson, C.H., 1981. Leaf surface micro-organisms as pathogen antagonists and as minor pathogens. In: Jenkyn, J.F. \& Plumb, R.T. (Eds), Strategies for the control of cereal disease. Blackwell Scientific Publications, Oxford, p. 109-121.

Dickinson, C.H. \& Walpole, P.R., 1975. The effect of late application of fungicides on the yield of winter wheat. Explor. Husb. 29: 23-28.

Dunn, C.L., Beynon, K.I., Brown, K.F. \& Montagne, J.W.T., 1971. The effect of glucose in leaf exudates upon the biological activity of some fungicides. In: Preece, T.F. \& Dickinson, C.H. (Eds), Ecology of leaf surface micro-organisms. Academic Press, London, p. 491-507.

Fokkema, N.J., 1971. The effect of pollen in the phyllosphere of rye on colonization of saprophytic fungi and on infection by Helminthosporium sativum and other leaf pathogens. Neth. J. Pl. Path. 77 (suppl. 1): 1-60.

Fokkema, N.J., 1981. Fungal leaf saprophytes, beneficial or detrimental? In: Blakeman, J.P. (Ed.), Microbial ecology of the phylloplane. Academic Press, London, p. 433-454.

Fokkema, N.J., 1983. In: INRA (Ed.), Les antagonismes microbiens. 24ème colloque SFP, Bordeaux, 26-28 mai 1983. (Les colloques de l'INRA no. 18).

Fokkema, N.J., den Houter, J.G., Kosterman, Y.J.C. \& Nelis, A.L., 1979. Manipulation of yeasts of field-grown wheat leaves and their antagonistic effect on Cochliobolus sativus and Septoria nodorum. Trans. Br. Mycol. Soc. 72: 19-29.

Fokkema, N.J. \& Meulen, F. van der, 1976. Antagonism of yeast-like phyllosphere fungi against Septoria nodorum on wheat leaves. Neth. J. PI. Path. 82: 13-16.

Fokkema, N.J., Riphagen, I., Poot, R.J. \& De Jong, C., 1983. Aphid honeydew, a potential

Neth. J. Pl. Path. 90 (1984) 
stimulant of Cochliobolus sativus and Septoria nodorum and the competitive role of saprophytic mycoflora. Trans. Br. mycol. Soc. 81: 355-363.

Kataria, H.R. \& Grover, R.K., 1978. Reversal of toxicity of some systemic and non-systemic fungitoxicants by chemicals. Z. PflKrankh., PflPath., PflSchutz 85: 76-83.

Mappes, C.J. \& Hampel, M., 1977. Yield responses of winter barley to late fungicide treatments. Proceedings 1977 Brit. Crop Protect. Conf. - Pests and Diseases 1: 49-55.

Priestly, R.H. \& Bayles, R.A., 1982. Effect of fungicide treatment on yield of winter wheat and spring barley cultivars. Pl. Path. 31: 31-37.

Rabbinge, R., Drees, E.M., Graaf, M. van der, Verberne F.C.M. \& Wesselo, A., 1981. Damage effects of cereal aphids in wheat. Neth. J. Pl. Path. 87: 217-232.

Rabbinge, R., Mantel W.P. \& Sinke, J., 1983. Crop physiological background of damage due to cereal aphids and mildew in winter wheat. Meded. Fac. Landb. Wet., Rijksuniv. Gent. 48(4): 1159-1168.

Sokal, R.R. \& Rohlf, F.J., 1981. Biometry. Freeman, San Francisco, second ed.

Spiertz, J.H.J., 1982. Physiological and environmental determinants of potential crop productivity. Proc. 12th Congr. Int. Potash. Institute, Bern. p. 27-46.

Vos, N.M. de, 1977. Wheat. In: Alberda, Th. (Ed.), Crop photosynthesis: methods and compilation of data obtained with a mobile field experiment. Agric. Res. Rep. 865: 22-30.

Zadoks, J.C., 1981. Een decimale code voor de ontwikkelingsstadia van granen. Gewasbescherming 12: 219-229. 